\author{
ЛОБІЮВАННЯ В \\ СИСТЕМІ СОЩАЛЬНО- \\ ЕКОНОМІЧНИХ \\ ПРІОРИТЕТІВ \\ УКРАЇНИ ${ }^{4}$
}

\author{
ГОЛОВНЯ О.М., \\ доктор економічних наук, доцент \\ кафеори менеджменту \\ зовнішньоекономічної діяльності, готельно- \\ ресторанної справи та туризму, \\ Вінницький національний \\ аграрний університет \\ (м. Вінниця)
}

Статтю присвячено дослідженню лобістської діяльності як важливої складової процесу формування державної політики соиіально-економічного розвитку. Автор наголошує, що українська економіка має високу залежність від зовнішньої кон'юнктури, а також високу чутливість до світових економічних коливань. Відповідно, відкритість економіки країни $\epsilon$ ミ вагомим чинником ї̈ залучення до сучасних ланцюгів створення доданої вартості, глобальноі та регіональної інтегрованості. Визначено, щзо забезпечення повноцінного державноприватного партнерства у сучасному світі потребує лобіювання як иілеспрямованого впливу на владу з боку громадськості з метою прийняття цілої низки економічних рішень.

Дослідження дозволило встановити, щу структура явища «лобіювання» включає три основних компоненти: об'єкт, суб'єкт, технології. Таким чином, лобіювання у сучасному світі постає як складний прочес иілеспрямованого впливу на владу з метою отримання бажаного рішення. Метою діяльності лобістських структур найчастіше є низка рішень, серед яких вагоме місие займає прийняття законів, щзо стосуються питань економічної діяльності та інвестиційної, інноваційної, митної політик.

Виявлено, щзо лобіювання потребує розгалуженої мережі інституціий та організацій від профспілок та власників підприємств до мас-медіа та організацій громадянського суспільства. Вагомий вплив на просування національних сочіально-економічних пріоритетів здійснюють консалтингові фірми, мас-медіа, недержавні аналітичні иентри, різноманітні галузеві об 'єднання. Лобіювання в розвинених країнах є інструментом співпраці і комунікації, який призводить до прийняття прогресивних рішень, вигідних як бізнесу, так і суспільству. Це підтверджує прогресивний досвід США та ЄС.

У дослідженні звертається увага на те, щзо в Україні практикується переважно тіньове лобіювання, оскільки діяльність вітчизняних лобістів не регламентується ніякими законодавчими актами. Автор ие пояснюе тим, щзо нашій бізнесовій і політичній верхівці вигідна така взаємодія, коли великі фінансово-промислові групи спонсорують $i$ великих політиків, які володіють впливом на ухвалення рішень, і дорогі виборчі кампанії.

Ключові слова: лобіювання, національна економіка, відкритість економіки країни, соціально-економічний розвиток, фінансово-промислові групи.

Табл.: 4. Рис.: 3. Літ.: 15. 


\title{
LOBBYING IN THE SYSTEM OF SOCIO-ECONOMIC PRIORITIES OF UKRAINE
}

\author{
GOLOVNYA Olena, \\ Doctor of Economic Sciences, \\ Associate Professor of the Department of International Management, \\ Hotel and Restaurant Business and Tourism, \\ Vinnytsia National Agrarian University \\ (Vinnytsia)
}

The article is devoted to the research of lobbying activities as an important component of the process of forming the state policy of socio-economic development. The author emphasizes that the Ukrainian economy has a high dependence on the external environment, as well as high sensitivity to global economic fluctuations. In turn, the openness of the country's economy is a significant factor in its involvement in modern value chains, global and regional integration. It is determined that securing a full-fledged public-private partnership in the modern world requires lobbying as a deliberate influence on the public by the authorities in order to make a number of economic decisions.

The study found that the structure of the phenomenon of "lobbying" includes three main components: object, subject, technology. Thus, lobbying in the modern world appears to be a complex process of purposeful influence on the government in order to obtain the desired solution. The purpose of lobbying structures activities is often a series of decisions, in which the adoption of laws concerning economic activity and investment, innovation, and customs policies is of great importance.

It is revealed that lobbying requires an extensive network of institutions and organizations from trade unions and business owners to the media and civil society organizations. Significant influence on the advancement of national socio-economic priorities is exercised by consulting firms, mass media, non-state think tanks, various industry associations. Lobbying in developed countries is a tool for cooperation and communication that leads to progressive decisions that are beneficial to both business and society. This confirms the progressive experience of the USA and the EU.

The study draws attention to the fact that Ukraine mainly practices shadow lobbying, since the activities of domestic lobbyists are not regulated by any legislative acts. This is explained by the fact that our business and political leaders benefit from such interaction when large financial and industry groups sponsor, large decision-makers and expensive electoral campaigns.

Keywords: lobbying, national economy, openness of the country's economy, socio-economic development, financial-industrial groups.

Tabl.: 4. Fig.: 3. Lit.: 15.

\section{ЛОББИРОВАНИЕ В СИСТЕМЕ СОЩИАЛЬНО-ЭКОНОМИЧЕСКИХ ПРИОРИТЕТОВ УКРАИНЫ}

ГОЛОВНЯ Е.М. доктор экономических наук, доцент кафедры менеджмента внешнеэкономической деятельности, гостинично-ресторанного дела и туризма, Винницкий национальный аграрный университет 


\begin{abstract}
Статья посвящена исследованию лоббистской деятельности как важной составляюшей процесса формирования государственной политики соичиальноэкономического развития. Автор отмечает, что украинская экономика имеет высокую зависимость от внешней конъюнктуры, а также высокую чувствительность к мировым экономическим колебаниям. В свою очередь, открытость экономики страны является весомым фактором ее привлечения к современным ичепям создания добавленной стоимости, глобальной и региональной интегрированности. Определено, что обеспечение полноценного государственно-частного партнерства в современном мире требует лоббирования, как целенаправленного воздействия на власть со стороны общественности с иелью принятия изелого ряда экономических решений.
\end{abstract}

Исследование позволило установить, что структура явления «лоббирование» включает три основных компонента: объект, субъект, технологии. Таким образом, лоббирование в современном мире выступает как сложный процесс иеленаправленного воздействия на власть с целью получения желаемого решения. Целью деятельности лоббистских структур чаще всего есть ряд решений, среди которых важное место занимает принятия законов, касаюшихся вопросов экономической деятельности и инвестиционной, инновачионной, таможенной политики.

Выявлено, что лоббирование требует разветвленной сети учреждений и организаций - от профсоюзов и владельцев предприятий к СМИ и организаџий гражданского общества. ミ๋ Существенное влияние на продвижение национальных социально-экономических осуществляют консалтинговые фирмы, масс-медиа, негосударственные аналитические иентры, разнообразные отраслевые объединения. Лоббирование в развитых странах является инструментом сотрудничества и коммуникации, который приводит к принятию прогрессивных решений, выгодных как бизнесу, так и обществу. Это подтверждает прогрессивный опьыт США и ЕС.

В исследовании обращается внимание, что в Украине наблюдается преимущественно теневое лоббирование, поскольку деятельность отечественных лоббистов не регламентируется законодательными актами. Автор это объясняется тем, что нашей бизнесовой и политической верхушке выгодна такое взаимодействие, когда крупные финансово-промышленные группы спонсируют больших политиков, обладающих влиянием на принятие решений, и проводящие дорогие избирательные кампании.

Ключевые слова: лоббирование, национальная экономика, открытость экономики страны, социально-экономическое развитие, финансово-промышленные группы.

Табл.: 4. Рис.: 3. Лит.: 15.

Постановка проблеми. Головним економічним пріоритетом для України залишається утримання макроекономічної стабільності, посилення спроможності великого, середнього та малого бізнесу до довгострокового зростання і розвитку. Але сьогодні Україна знаходиться на економічному роздоріжжі, яке сформувалося за рахунок поєднання низки економічних ризиків, що посилюють невизначеність і поглиблюють складнощі запровадження соціально-економічного прискорення. Саме таке прискорення є основою не лише досягнення підвищення добробуту громадян, але й покращення сприйняття 今ั країни міжнародною економічною спільнотою.

Перехід національної економіки до нової прогресивної моделі розвитку Зे. передбачає формування ефективної державної політики соціально-економічного розвитку. Пришвидшити формування такої політики та реалізувати соціально- 
економічні інтереси України у світовому просторі можна за допомогою лобіювання.

12 лютого 2020 року у Верховній Раді України зареєстровано законопроєкт №3059 про державну реєстрацію суб'єктів лобіювання та здійснення лобіювання в Україні. Поданий проєкт закону передбачає створення єдиного відкритого реєстру лобістів, які відстоюють інтереси окремих держав та компаній. При цьому кожен, хто взяв гроші за лобізм, особливо з-за кордону, має прозвітувати, за що він їх отримав. Зі свого боку лобіст зобов'язаний зареєструватися сам та реєструвати кожен свій контракт лобіювання.

В економічній літературі висвітлюються різні підходи до розуміння змісту поняття лобіювання. Завадський Й. С. трактує це поняття як дії державних органів, спрямовані на підтримку окремих галузей і сфер економіки, регіонів, підприємств, соціальних груп. Відповідно лобістом вважає агента, представника великих монополій, який здійснює тиск на законодавців в інтересах монополістів [4].

Підприємницький лобізм у різних формах існує давно - 3 моменту зародження підприємницької діяльності і появи у бізнесменів необхідності і бажання використовувати контакти з владою. Тому ця тема залишається в полі зору економістів, владних структур і громадської думки, але і привертає до себе все більшу увагу і стає об'єктом всебічного дослідження.

Важливим елементом соціально орієнтованої національної економіки $є$ напрацювання ефективної системи протистояння лобіюванню інтересів приватних груп, які впливають на прийняття вищих управлінських рішень, послідовне відстоювання національних економічних інтересів і реалізації державної політики в напрямку захисту інтересів більшості населення. Такі приватні структури конкурують на внутрішньонаціональному економічному просторі та часто лобіюють замість національних інтереси іноземних держав, транснаціональних структур тощо.

Лобіювання є процесом цілеспрямованого пошуку і встановлення зв'язків iз посадовими особами 3 метою впливу на прийняття вигідних рішень в інтересах інших юридичних осіб, передусім великих монополій. Досить часто саме великі приватні компанії конкурують на внутрішньонаціональному економічному просторі, одночасно лобіюючи замість національних інтереси іноземних держав, транснаціональних структур тощо.

Аналіз останніх досліджень і публікацій. Різним аспектам формування ефективної державної політики соціально-економічного розвитку присвячені численні праці вітчизняних науковців, серед яких варто особливо відзначити Гончарук І.В. [2], Жилінську О. [3], Завадського Й. С. [4], Кінаш І.П. [5], Куценко В.І. [7], Юрчишина В. [15] та інших. У прискореній реалізації державної політики національної економіки актуалізується питання лобіювання соціальноекономічних пріоритетів. Численні дослідження присвячені вивченню зарубіжного досвіду лобіювання соціально-економічних інтересів країни. Цьому 
питанню свого часу приділили увагу Нестерович В. [9], Сумська В.В. [12], Трофименко А.В. [13] та багато інших.

Формулювання цілей статті. Дослідженню економічного лобізму приділяється, на наш погляд, недостатня увага. Це явище розглядається 3 політологічними, соціологічними, юридичним ухилом. Але як економічне явище лобізм практично не вивчається. Мета статті - дослідити лобістську діяльність як складову процесу формування ефективної національної політики соціальноекономічного розвитку.

Виклад основного матеріалу дослідження. Українська економіка має високу залежність від зовнішньої кон'юнктури, а також високу чутливість до світових економічних коливань. У несприятливих умовах зниження динаміки глобальної економіки може спровокувати негативну реакцію національних суб'єктів господарювання, підвищити різні економічні ризики для України у найближчі роки.

Відкритість економіки країни $\epsilon$ вагомим чинником iї залучення до сучасних ланцюгів створення доданої вартості, глобальної та регіональної інтегрованості. Вища інтегрованість означає вищий приплив прямих іноземних інвестицій, а $з$ тим і зростання продуктивності, і посилення конкурентних позицій національних виробників на внутрішніх і світових ринках $[15$, с. 8$]$.

Радикальна оптимізація світового виробництва 3 переміщенням певних його ланок у країни з нижчими витратами призводить до формування глобальних мереж виробництва і торгівлі. Експерти Світової організації торгівлі довели позитивну залежність між участю у глобальних ланцюгах доданої вартості та темпами економічного зростання: 30 найбільш інтегрованих до глобальних ланцюгів країн, що розвиваються, за останні два десятиріччя мали середній темп економічного зростання на рівні 3,3 \%; 30 країн, які були мінімально інтегровані. в ці процеси, зростали щорічно в середньому на $0,7 \%$. Такі процеси будуть $\mathrm{i}$ надалі поглиблюватись, а поступова лібералізація торгівлі усуватиме адміністративні й бюрократичні перепони руху товарів, надалі спрощуючи участь у глобальних мережах виробництва товарів і комплектуючих та надання послуг [3].

Здатність країни брати участь у світових мережах виробництва та торгівлі, отримуючи від цього вигоди, залежить від ії залучення у ланцюги створення доданої вартості - мережевізації. Можливість залучення суб'єктів господарювання до глобальних мереж зумовлюють наступні чинники: 1) якість бізнес-середовища; 2) рівень політичного та економічного ризиків; 3) нормативно-правові та податкові регулятори; 4) розвиток технологій; 5) вартість та швидкість логістичних операцій; 6) якість цифрової передачі даних.

Участь України у світових мережах виробництва та торгівлі є лише : засобом досягнення стратегічної мети. Стратегічна мета такої участі полягає у І відповіді на наступне питання: «які обсяги доданої вартості здатна країна отримати від участі в мережах за показниками: створення нових робочих місць, 
зростання доходів іï громадян, розповсюдження новітніх технологій, темпів збалансованого розвитку?» [3].

В Україні наразі не сформовано основ цивілізованого лобізму, хоча наприкінці 90-х рр. ХХ ст. у державі відбулося усвідомлення необхідності правового врегулювання лобістської діяльності, яке вилилось у низку законодавчих ініціатив. У таких країнах Західної Свропи, як Франція, Австрія, функціонують інститути соціально-економічних рад, які виконують роль своєрідного лобістського парламенту. У Німеччині лобістську діяльність (до речі, термін «лобі» і всі похідні від нього німці намагаються не використовувати, тому замінили його словосполученням «групи інтересів») регламентує низку правових актів.

Але варто враховувати, що процес легалізації у правовому полі сфери government relations (спроби компаній вплинути на дії і заходи влади 3 метою досягнення певної мети) потребує підтримки з боку громадськості. Саме тому на замовлення компаніï SIC Group Ukraine в Україні було проведено загальнонаціональне соціологічне опитування щодо суспільного розуміння та ставлення до лобістської діяльності, а також форм комунікації між суспільством, суб'єктами господарювання та владою.

Загальнонаціональне соціологічне опитування продемонструвало те, як українці ставляться до лобістської діяльності. Дослідження проводилось у 24-х областях України Результати опитування представлені на рис. 1. та рис. 2. Лобізм - це спроба організацій або окремих громадян впливати не тільки на ухвалення, відхилення, чи зміну законів у парламенті, а також спроба впливати на адміністративні рішення уряду, спираючись на підтримку не тільки обраних депутатів, а й різних політичних партій, державних і недержавних установ та підтримку громадськості через засоби масової інформації.

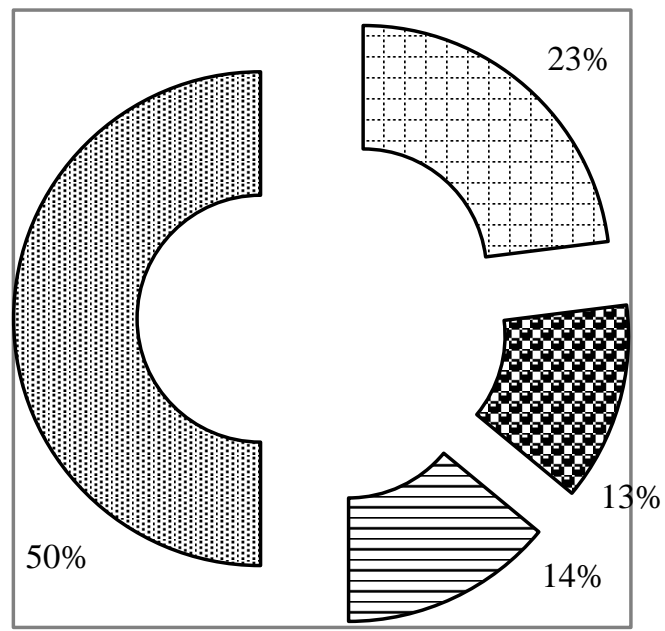

$\square$ важко визначитись з відповіддю, $23 \%$

巴пзитивне, $13 \%$

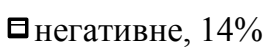

目 в залежності від ситуації, 50\%

Рис. 1. Відношення до практики реалізації інтересів різних груп громадян шляхом впливу на органи державної влади, у \% до опитаних Джерело: складено автором за [8] 
До лобістів належать передусім представники профспілок, ділові асоціації, громадсько-політичні об'єднання, комітети, комісії.

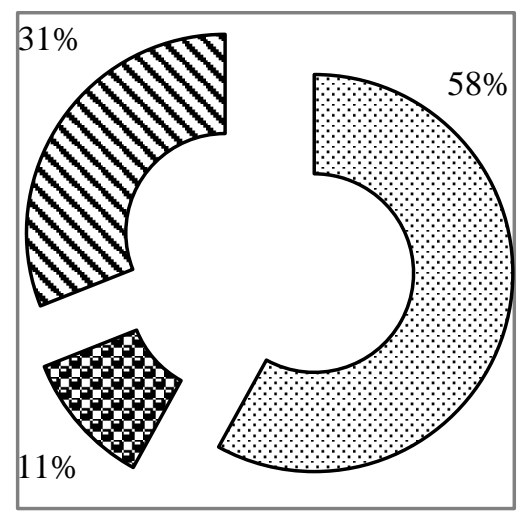

Рис. 2. Розуміння сутності лобістської діяльності громадянами України, у \% до опитаних

Джерело: складено автором за [8]

Професійна винагорода лобіста-посередника є одним з видів роялті. Роялт лобіста - це його винагорода за здатність налагодити, гармонізувати відносини між представниками бізнесу та влади, врегулювати інтереси представників цих двох спільнот. Це гонорар посередника-лобіста за його зусилля щодо налагодження контактів і за використовуваний ним лобістський досвід і знання. Плата за лобізм щоразу встановлюється у вигляді певної частки від доходу, отримуваного суб'єктом лобіювання від використання інтелектуального ресурсу лобіста. У цьому полягає основний економічний зміст лобізму.

Метою діяльності лобістських структур найчастіше $\epsilon$ низка рішень: а) прийняття законів, які стосуються питань економічної діяльності та інвестиційної, інноваційної, митної політик; б) законодавча діяльність у банківській, кредитно-фінансовій та страховій сферах; в) законодавча діяльність у різних секторах економіки, у тому числі в аграрному секторі, у паливноенергетичному комплексі, легкій промисловості; г) бюджетний процес, затвердження спеціальних державних програм розвитку, будівництва та державних замовлень, що будуть фінансуватись 3 бюджету; е) процес приватизації.

Лобісти можуть представляти інтереси різних кіл громадськості, організацій, профспілок, асоціацій, компаній, фірм та сприяють: 1) отриманню державних гарантій під інвестиційні та інноваційні проєкти; 2) вирішенню питань щодо надання конкретним підприємствам передбачених бюджетом дотацій, субсидій та субвенцій (особливо в сільському господарстві); 3)。 вирішенню питань щодо збільшення або зменшення квот на експорт (імпорт) певної продукції; 4) ліцензуванню окремих видів господарської діяльності; 5) утриманню вигідних державних замовлень, кредитів, допомоги, пільг; 6) 
отриманню вигідних преференцій; 7) створенню та реєстрації нових суб'єктів господарювання; 8) придушенню конкурентів тощо.

Щодо відповідного розуміння суб’єкта лобіювання, та його змістового наповнення, то в економічній літературі немає однозначності поглядів, що пояснюється різними підходами до цього питання різними сферами економіки. Виділяють два основних підходи до розуміння лобіювання в сфері важелів регулювання економіки, залежно від рівня узагальнення. Перший підхід полягає в лобіюванні як реалізація прав громадян звертатися з клопотанням до органів державної влади для вирішення особистих соціально-економічних проблем. Суть другого підходу в лобіюванні як професійній діяльності співробітників або спеціальних консультантів, найнятих різними суб'єктами господарювання, в т. ч. підприємствами, компаніями, діловими й професійними асоціаціями, профспілками та іншими групами, для представлення інтересів цих організацій у процесі вибору ефективних методів і економічних важелів регулювання економічних процесів та формування державної економічної політики.

Звідси також множинність у понятійному апараті: «лобіст», «група інтересів», «група впливу», «зацікавлена група», «суб’єкт лобіювання», з одного боку, i «державні структури», «органи державної влади», «органи державної влади та місцевого самоврядування», «посадові особи», «об'єкт лобіювання» - 3 іншого. Змістовне наповнення також досить багатогранне: від лобіста як «особи, яка намагається вплинути на законодавчий процес» до лобіста як «фізичної особи, що зареєстрована у встановленому законом порядку, від власного імені або в інтересах та на замовлення третіх осіб (клієнтів), здійснює легальний вплив на чітко визначені законом органи державної влади й органи місцевого самоврядування, а також на їхніх посадових осіб».

У світовій практиці існують традиційні ресурси лобіювання: адміністративно-управлінський ресурс - наявність зв'язків у владних структурах, що втілюється в постановах, рішеннях, законодавчих актах державних органів влади; фінансовий ресурс - це кошти, які різні структури та суб'єкти господарювання можуть виділити для реалізації потрібних рішень. Ці кошти необхідні для проведення якісного моніторингу, аналізу, пошуку, PRакцій у певні проєкти; інформаційний ресурс - отримання необхідної достовірної інформації для підтримки власних поглядів і позицій. Він реалізується під час збору інформації у різних заходах, акціях, кампаніях, стратегіях.

Структура явища «лобіювання» включає три основних компоненти:

- об’єкт - органи державної влади, здебільшого законодавчі та виконавчі;

- суб'єкт - суспільні групи, які усвідомили свій спільний економічний інтерес і прагнуть його реалізувати (групи тиску);

- технології - методи здійснення комунікації між суб'єктом і об’єктом лобіювання (рис. 3).

Таким чином, лобіювання часто є сполучною ланкою між соціальними потребами населенням та державою, між економічною метою та правовими засобами іiі вирішення, природним механізмом виявлення, узгодження та 
втілення інтересів учасників суспільних відносин в офіційній політиці владних суб'єктів. Зазначене наштовхує на висновок про величезну соціальноекономічну цінність лобіювання, його соціально-економічну спрямованість, соціально-економічне походження, сутність, природу.

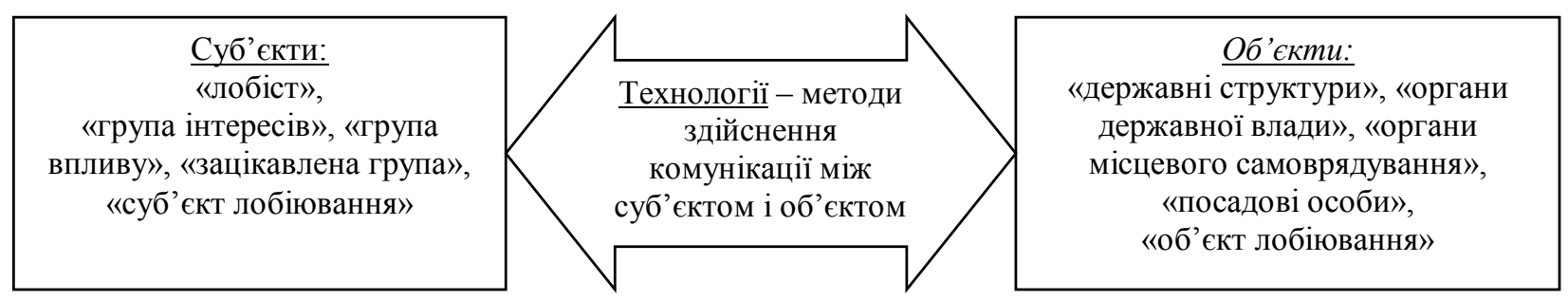

Джерело: розробка автора

\section{Рис.3. Структура явища «лобіювання»}

Стосовно нормативно-правових актів, покликаних регулювати лобіювання, немає дефініції останнього. Натомість Акт про відкритість лобіювання від 1995 року у США (Lobbying Disclosure Act of 1995), Кодекс поведінки лобістів Австралії (Lobbying Code of Conduct), Закон про лобістську діяльність Литви (Law on Lobbying Activities) та польський Акт про лобістську діяльність у законодавчому процесі (Ustawa o dzialalnosci lobbingowej w procesie stanowienia prawa) визначають i використовують поняття «лобістська діяльність».

Світовий ринок лобістських послуг енергійно розвивається, особливо це можна простежити на прикладі американського та європейського ринку. У Свропі лобізм носить позитивний характер і має за мету покращення стандартів життя всього суспільства. Незважаючи на те, що на рівні ЄС немає єдиного закону про лобіювання, також єдиного закону про лобіювання не мають багато країн ЄС. Але це не заважає розвитку і зростання, оскільки лобіювання в ЄС стало невід'ємною частиною суспільного життя.

На рівні ЄС сформовано реєстр прозорості (Transparency Register), який має в розпорядженні Європейська комісія. Реєстрація в реєстрі є безкоштовною та відкритою для всіх суб'єктів господарювання. До реєстру можуть бути включені як галузеві асоціації, аналітичні центри, лобістські фірми, так і різні громадські організації [1].

Участь у реєстрі прозорості не гарантує виділення грантів для господарчих суб'єктів чи учасників бізнесу. Основна мотивація бути учасником реєстру прозорості - це можливість отримувати оперативну аналітичну інформацію за потрібною тематикою, мати можливість брати участь у комітетських обговореннях, а також отримати можливість акредитації для відвідування засідань Свропарламенту, Сврокомісії та їхніх органів.

Загалом у Transparency Register зареєстровано 11663 організації зі 124 空 країн. Найбільше організацій у реєстрі з Бельгії та Німеччини - 2141 і 1484суб'єктів реєстру відповідно. Україна за кількістю зареєстрованих організацій 
посідає 36 місце між Японією і Сербією. Від України до реєстру прозорості внесено 17 організацій [1].

У таблиці 1 представлені країни-лідери за фінансуванням лобіювання, на першій позиції знаходиться Південна Корея.

Таблиия 1

Топ-10 країн світу за фінансуванням лобіювання

\begin{tabular}{|c|c|c|}
\hline № п/п & Країна & Витрати на лобіювання, дол США \\
\hline 1 & Південна Корея & 70567305 \\
\hline 2 & Японія & 51653098 \\
\hline 3 & Об’єднані Арабські Емірати & 27354725 \\
\hline 4 & Ізраїль & 24288581 \\
\hline 5 & Ірландія & 23482311 \\
\hline 6 & Китай & 19448463 \\
\hline 7 & Кайманові острови & 19011856 \\
\hline 8 & Саудівська Аравія & 18499129 \\
\hline 9 & Канада & 18151554 \\
\hline 10 & Німеччина & 17733818 \\
\hline
\end{tabular}

Джерело: складено автором за [8]

Важливим методологічним аспектом в ідентифікації лобіювання $\epsilon$ концепція його взаємозв'язку з такими поняттями: a) public relations (PR) (зв'язки 3 громадськістю) - управління масивом інформації, що виникають між різними суб'єктами господарювання та громадськістю; б) public affairs industry (PA) (індустрія суспільних справ) - побудова та розвиток стосунків між підприємством та політиками, урядом та іншими особами, від яких залежать рішення; в) government relations (GR) (взаємодія з органами державної влади) діяльність спеціально уповноважених працівників великих комерційних структур та фінансово-промислових груп з ведення роботи компаній у владнополітичному середовищі.

Лобіювання часто можливе за рахунок просування інтересів різних фінансово-промислових груп, неурядових організацій або етнічних спільнот для досягнення певного рішення. Лобісти можуть відстоювати державні інтереси на міжнародній арені або громадські чи приватні інтереси всередині країни. Як відомо, фінансово-промислові групи поєднують у собі переваги об'єднання фінансового і промислового капіталів, які забезпечують отримання додаткового доходу. Такі підприємства $є$ важливими наповнювачами ВВП.

За галузевою ознакою до рейтингу ТОП-100 підприємств, які поповнювали державний бюджет та формували ВВП у 2018 році потрапили: 22 компанії добувної сфери, 10 компаній енергетичного сектору, 8 фірм, що займаються виробництвом міцних спиртних напоїв, а також вина i пива, 7 металургійних компаній, 1 машинобудівний завод, 9 банків, 4 компанії, які займаються виробництвом тютюнових виробів, 4 компанії сфери зв'язку, 5 підприємств оптової торгівлі, 4 підприємства роздрібної торгівлі, 2 підприємства-виробники коксу та продуктів нафтопереробки, 1 підприємство харчової промисловості, 1 підприємство мобільного харчування, 1 автосалон, 1 поліграфічний комбінат, 1 підприємство, яке займається дослідженнями та 
експериментальними розробками, 1 представництво, яке займається дослідженням кон'юнктури ринку та виявленням громадської думки, 1 виробник іншого електричного устаткування.

Усі ці підприємства перерахували до зведеного бюджету України у 2018 році 291,7 млрд грн. У тому числі, НАК «Нафтогаз України» - 93 306,6 млн грн., тобто 23,3\% загальних податкових надходжень до зведеного бюджету України.

ПрАТ «Систем Кепітал Менеджмент» (System Capital Management, «SKM») перерахувала до зведеного бюджету України у 2018 році - 90 186,8 млн грн., або 22,6\% загальних податкових надходжень до зведеного бюджету України. «SCM»- це міжнародний бренд, представлений в 7 країнах Свропи $\mathrm{i}$ Північної Америки. Компанії і підприємства, що належать до SCM, працюють в гірничо-металургійній, енергетичній, банківській, телеко-мунікаційній, масмедійній, транспортній, сільськогосподарській, страховій і інших сферах. У портфель «SCM» входять більше 500 компаній і підприємств, на яких працюють близько 200 тисяч осіб.

НАЕК «Енергоатом»- 6 515,9 млн грн перерахували до зведеного бюджету України у 2018 році або 1,6 \% загальних надходжень усіх платників України.

Активна участь українських організацій у роботі європейського лобістського ринку пояснюється не тільки підписаною Угодою про асоціацію з $€ C$, а й прагматичними цілями. Наприклад, низка організацій здійснює підтримку товарообігу та просування українських товарів на ринках країн $€ С$. Найактивніших українських лобістів представлено в енергетичній галузі: ДТЕК, НАЕК «Енергоатом» і НАК «Нафтогаз України». Інші організації багато в чому просувають інтереси українського середнього бізнесу. Серед аналітичних та дослідницьких центрів 3 головним офісом в Україні зареєстровано «Інститут професійних комунікацій».

Власне участь у реєстрі часто має PR-характер і не реалізує лобістських функцій. Відтак, з 17 українських суб'єктів реєстру тільки три мають офіси в Бельгії. Незважаючи на це, представники чотирьох українських організацій з реєстру мають акредитацію у Європарламенті: ДТЕК - власність Ріната Ахметова; «Енергоатом» - держпідприємство; НАК «Нафтогаз України» держпідприємство; журнал Business Woman - власність Ганни Грисюк. Найбільше представництв у Бельгії мають організації з Німеччини і Франції 307 і 199 відповідно.

Український бізнес останніми роками все більше приєднується до бізнесасоціацій або до спеціалізованих галузевих асоціацій, які виконують функції представництва інтересів. Свропейська Бізнес Асоціація (EBA) і Американська

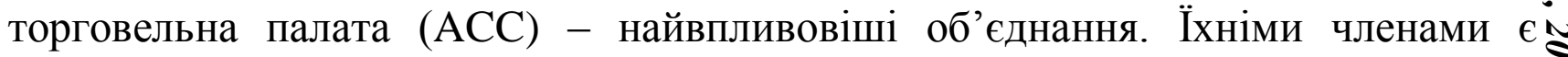
переважно середні та великі компанії, а також більшість міжнародних гравців, 丞 які працюють на українському ринку.

На базі цих організацій діють галузеві комітети, які беруть участь у розробці відповідних нормативних актів. Крім того, вони організовують зустрічі й заходи за участю представників органів влади, надсилають офіційні листи та 
звернення. Це престижні асоціації, до чиєї думки влада дослухається. Проте, 3 погляду окремої компанії їхні можливості все ж обмежені. В ЕВА близько 900 членів, в АСС приблизно 600, а тому вирішувати проблеми однієї компанії 3 їхною допомогою не вийде, адже вони зобов'язані враховувати побажання кожного члена. Тому для вирішення конкретних завдань або проблем однієї компанії слід розраховувати на свої сили. Щоб робити це ефективно, в Україні необхідно створювати класичний лобізм західного зразка [11].

Що стосується розкриття форм відкритого (демократичного) лобіювання, то класичним прикладом є Сполучені Штати Америки. Щоб упорядкувати роботу лобістів, запобігти їхнім протиправним діям розробляється чітке законодавство, яке регламентує систему лобіювання. У США, наприклад, ще від 1946 року функціонує федеральний закон про регламентацію лобістської діяльності. У США проблема лобіювання давно вирішена: лобізм закріплений на законодавчому рівні, його правила та дії чітко визначені. Лобіст, згідно - 3 актом "Про відкритість лобіювання" від 1995 року, - це особа, найнята клієнтами за фінансову або іншу винагороду для надання послуг, що включають більш ніж один лобістський контакт. Закон також доповнює, що лобістом $\epsilon$ особа, яка витрачає на лобістську діяльність не менше 20 \% часу, затраченого протягом півроку на надання послуг одному клієнту.

У таблиці 2 подано розподіл типів замовників серед лобістів у США. На передових позиціях знаходяться торговельні та бізнес-асоціації, бізнес-асоціації та професійні асоціації.

Лобістами у США переважно є люди 3 власною історією у політиці і зв'язками. Вони знають людей у Конгресі, Білому домі, медіа і можуть вийти на них та досягти бажаного для свого клієнта, використовуючи власні зв'язки. Фактично, це так званий «блат» в межах закону. У США, на відміну від України, такі послуги є офіційними, вони фіксуються, як і гроші, котрі за них платяться. Усі угоди є на сайті Мін'юсту США.

Таблиия 2

Розподіл типів замовників серед лобістів в США у 2018 році

\begin{tabular}{|c|l|c|c|}
\hline \multicolumn{1}{|c|}{ Топ п/п замовників } & \multicolumn{1}{|c|}{$\begin{array}{c}\text { Кількість, } \\
\text { одиниць }\end{array}$} & \% \\
\hline 1 & Групи громадян (citizen groups) & 329 & 26 \\
\hline 2 & Торговельні та бізнес асоціації & 265 & 21 \\
\hline 3 & Бізнес-корпорації & 179 & 11 \\
\hline 4 & Професійні асоціації & 140 & 7 \\
\hline 5 & Спеціаловані союзи та коаліції & 90 & 6 \\
\hline 6 & Профспілки & 77 & 3 \\
\hline 8 & Фонди та «мозкові центри» & 71 & 2 \\
\hline 9 & Навколоурядові асоціації & 38 & 3 \\
\hline 10 & Інститути і асоціації інститутів & 20 & 100 \\
\hline
\end{tabular}

Дюерело: складено автором за [8] 
Таблиця 3 демонструє витрати світових IT-гігантів на просування своїх інтересів (лобізм) на території США у 2018 році. На першому місці знаходиться корпорація Google.

Таблиия 3

Витрати світових IT-гігантів на на просування своїх інтересів (лобізм) на території США у 2018 році

\begin{tabular}{|c|l|c|}
\hline № n/п & Компанія & Витрати \\
\hline 1 & Google & 3,8 млн дол США \\
\hline 2 & Microsoft & 2,6 млн дол США \\
\hline 3 & Facebook & 1,6 млн дол США \\
\hline 4 & Apple & 960 тис дол США \\
\hline
\end{tabular}

Джерело: складено автором за [8]

Відзначимо, що недержавні та комерційні організації в США зобов'язані розкривати свої витрати на лобістську діяльність. Відомості про витрати на лобізм надходять до Палати представників Конгресу США і доступні для громадськості. Вплив на політичні рішення, лобізм у США -ड़ це багатомільярдний бізнес. Суспільство в США сприймає лобізм як невід'ємну частину демократії. Про це свідчить 35 тис. лобістів, офіційно зареєстрованих у Вашингтоні. У 2018 р. обсяг витрат на них склав понад 3,14 млрд дол.

Сьогодні у Вашингтоні не менше 100 людей лобіюють українські інтереси. Це все співробітники лобістських компаній, які діють в США офіційно.

Загальні витрати України на лобізм в США у 2018 році, дол. США

\begin{tabular}{|c|c|c|}
\hline № п/п & Показник & Витрати \\
\hline 1 & Витрачено Урядом України & 195000 \\
\hline 2 & Витрачено неурядовими організаціями & 1154546 \\
\hline
\end{tabular}

Джерело: складено автором за [8]

Головна проблема правового регулювання цієї діяльності полягає у розмежуванні законної діяльності лобістів і підкупу, адже часто поряд з лобізмом виникає корупція.

Висновки. Отже, в Україні практикується переважно тіньове лобіювання, оскільки діяльність вітчизняних лобістів не регламентується ніякими законодавчими актами. Це пояснюється тим, що нашій бізнесовій і політичній верхівці вигідна така взаємодія, коли великі фінансово-промислові групи спонсорують і великих політиків, що володіють впливом на ухвалення рішень, $\mathrm{i}$ дорогі виборчі кампанії цих партій, натомість маючи довірених людей, які представлятимуть їхні інтереси всюди (від парламенту і Офісу Президента України до найнижчих ланок влади на місцевому рівні).

Лобіювання в розвинених країнах $є$ інструментом співпраці і комунікації, який призводить до прийняття прогресивних рішень, вигідних як бізнесу, так i суспільству. Надбанням громадськості не раз ставали приклади, коли шляхом успішного лобіювання своїх інтересів в органах влади підприємці домагалися 
істотного посилення своїх позицій на ринках, яких значних преференцій порівняно зі своїми конкурентами.

Таким чином, лобіювання у сучасному світі постає як складний процес цілеспрямованого впливу на владу з метою отримання бажаного економічного чи політичного рішення. Лобіювання потребує розгалуженої мережі інституцій та організацій - від профспілок та власників підприємств до мас-медіа та організацій громадянського суспільства. Вагомий вплив на просування національних соціально-економічних пріоритетів на світовій політичній та соціально-економічній арені можуть здійснювати спеціалізовані консалтингові фірми та піар-компанії, мас-медіа, державні та недержавні аналітичні центри, різноманітні міжгалузеві об'єднання.

\section{Список використаних джерел}

1. Transparency Register. URL: https://ec.europa.eu/transparencyregister (дата звернення: 11.02.2020).

2. Гончарук I. B., Томашук I.В. Державне регулювання розвитку ресурсного потенціалу сільських територій: загальні аспекти. Економіка. Фінанси. Менеджмент: актуальні питання науки і практики. 2018. № 4. С. 1930.

3. Жилінська О. УКРАЇНА 2030: Доктрина збалансованого розвитку. Видання друге. Львів: Кальварія, 2017. 164 с.

4. Завадський Й. С., Осовська Г. В., Юшкевич О. О. Економічний словник. Київ : Кондор, 2007. 358 с.

5. Кінаш I. П. Теоретико-методологічні орієнтири формування механізму управління розвитком соціальної сфери України. Науковий вісник Мукачівського державного університету. Сер. : Економіка. 2015. Вип. 1. С. 14-17.

6. Кіржецький Ю. І., Ріжко Л. I., Кіржецька М. С. Функції галузевого лобіювання як елемент організаційно-економічного механізму взаємодії бізнесу та влади. Вісник Національного університету "Львівська політехніка". Логістика. 2017. № 863. С. 82-87.

7. Куценко В. I. Прогнозування соціальної безпеки: теоретикометодологічні аспекти. Економіка природокористування $i$ сталий розвиток. 2018. № 3-4. С. 71-75.

8. Лобізм в США: які країни витрачають найбільше коштів для просування своїх інтересів. URL: https://mind.ua/news/20187753-lobizm (дата звернення: 12.02.2020).

9. Несторович В. Стандарти Організації економічного співробітництва та розвитку щодо урегулювання лобіювання. Історико-правовий часопис. 2016. № 1 . С. $75-79$.

10. Осипова Н. О. Соціально-економічна обумовленість практик лобізму. Грані. 2013. № 9. С. 133-139.

11. Сipi кардинали бізнесу. URL: https://business.ua/business/4951-sirikardynaly-biznesu (дата звернення: 11.02.2020). 
12. Сумська В. В. Лобіювання як інструмент публічного врядування: зарубіжний досвід. Теорія та практика державного управління. 2011. Вип. 4. C. 491-497.

13. Трофименко А. В. Передумови та етапи ухвалення закону про лобіювання в Канаді. Грані. 2014. № 7. С. 113-118.

14. Халковський O. M. Лобіювання економічних інтересів підприємницької діяльності як форма прояву корупції. Науковий часопис НПУ імені М. П. Драгоманова. Серія 18 : Економіка і право. 2012. Вип. 19. С. 73-79.

15. Юрчишин В. Соціально-економічний вимір України в період зміни політичних еліт. Київ: Разумков центр, 2019. 46 с.

\section{References}

1. Transparency Register. URL: https://ec.europa.eu/transparencyregister (data zvernennia: 11.02.2020)

2. Goncharuk I.V., Tomashuk I.V. (2018). Derzhavne rehulyuvannya rozvytku resursnoho potentsialu sil's'kykh terytoriy: zahal'ni aspekty [State regulation of rural s. resource development: general aspects]. Ekonomika. Finansy. Menedzhment: aktual'ni pytannya nauky i praktyky. Economy. Finances. Management: Topical issues of science and practice. № 4. S. 19-30. [in Ukrainian].

3. Zhylinska O. UKRAINA 2030: Doktryna zbalansovanoho rozvytku [The doctrine of balanced development]. Vydannia druhe. Lviv: Kalvariia, 2017. 164 s. [in Ukrainian].

4. Zavadskyi Y. S., Osovska H. V., Yushkevych O. O. (2007). Ekonomichnyi slovnyk [Economic Dictionary]. Kyiv : Kondor, 358 c. [in Ukrainian].

5. Kinash I. P. (2015). Teoretyko-metodolohichni oriientyry formuvannia mekhanizmu upravlinnia rozvytkom sotsialnoi sfery Ukrainy [Theoretical and methodological guidelines for the formation of a mechanism for managing the development of the social sphere of Ukraine]. Naukovyi visnyk Mukachivskoho derzhavnoho universytetu - Scientific Bulletin of Mukachevo State University . Ser. : Ekonomika. Vyp. 1. S. 14-17. [in Ukrainian].

6. Kirzhetskyi Yu. I., Rizhko L. I., Kirzhetska M. S. (2017). Funktsii haluzevoho lobiiuvannia yak element orhanizatsiino-ekonomichnoho mekhanizmu vzaiemodii biznesu ta vlady [Functions of sectoral lobbying as an element of organizational and economic mechanism of interaction between business and government]. Visnyk Natsionalnoho universytetu "Lvivska politekhnika". Lohistyka Bulletin of the National University "Lviv Polytechnic". Logistics. № 863. S. 82-87. [in Ukrainian].

7. Kutsenko V. I. (2018). Prohnozuvannia sotsialnoi bezpeky: teoretykometodolohichni aspekty [Predicting social security: theoretical and methodological 
aspects]. Ekonomika pryrodokorystuvannia $i$ stalyi rozvytok - Environmental Economics and Sustainable Development. № 3-4. S. 71-75. [in Ukrainian].

8. Lobizm v SShA: yaki krainy vytrachaiut naibilshe koshtiv dlia prosuvannia svoikh interesiv [Lobbying in the USA: which countries spend the most money to promote their interests]. URL: https://mind.ua/news/20187753-lobizm (data zvernennia: 12.02.2020)

9. Nestorovych V. (2016). Ctandarty Orhanizatsii ekonomichnoho spivrobitnytstva ta rozvytku shchodo urehuliuvannia lobiiuvannia [Standards of the Organization for Economic Cooperation and Development for the regulation of lobbying]. Istoryko-pravovyi chasopys - Historical law journal. № 1. S. 75-79. [in Ukrainian].

10. Osypova N. O. (2013). Sotsialno-ekonomichna obumovlenist praktyk lobizmu [Socio-economic conditionality of lobbying practices]. Hrani - The faces. № 9. S. 133-139. [in Ukrainian].

11. Siri kardynaly biznesu [Gray business cardinals]. URL: https://business.ua/business/4951-siri-kardynaly-biznes (data zvernennia: 11.02.2020)

12. Sumska V. V. (2011). Lobiiuvannia yak instrument publichnoho vriaduvannia: zarubizhnyi dosvid [Lobbying as a tool of public governance: foreign experience]. Teoriia ta praktyka derzhavnoho upravlinnia - Public administration theory and practice. Vyp. 4. S. 491-497.

13. Trofymenko A. V. (2014). Peredumovy ta etapy ukhvalennia zakonu pro lobiiuvannia v Kanadi [Prerequisites and stages for the adoption of Canada Lobbying Law]. Hrani - The faces. № 7. S. 113-118. [in Ukrainian].

14. Khalkovskyi O. M. (2012). Lobiiuvannia ekonomichnykh interesiv pidpryiemnytskoi diialnosti yak forma proiavu koruptsii [Lobbying the economic interests of business as a form of corruption]. Naukovyi chasopys NPU imeni M. P. Drahomanova. Seriia 18 : Ekonomika i pravo - Scientific journal of MP Dragomanov NPU. Series 18: Economics and Law. Vyp. 19. S. 73-79. [in Ukrainian].

15. Iurchyshyn V. (2019). Sotsialno-ekonomichnyi vymir Ukrainy v period zminy politychnykh elit [Socio-economic dimension of Ukraine in the period of change of political elites]. Kyiv: Razumkov tsentr, 46 c. [in Ukrainian].

\section{Відомості про автора}

ГОЛОВНЯ Олена Михайлівна - доктор економічних наук, доцент кафедри менеджменту зовнішньоекономічної діяльності, готельно-ресторанної справи та туризму Вінницького національного аграрного університету (вул. Сонячна, 3, м. Вінниця, 21008, e-mail: ellens@ @eta.ua).

GOLOVNYA Olena - Doctor of Economic Sciences, Associate Professor of the Department of International Management, Hotel and Restaurant Business and 
Tourism, Vinnytsia National Agrarian University (21008, Vinnytsia, 3 Soniachna st, 3, e-mail: ellens@meta.ua).

ГОЛОВНЯ Елена Михайловна - доктор экономических наук, доцент кафедры менеджмента внешнеэкономической деятельности, гостиничноресторанного дела и туризма Винницкого национального аграрного университета, ул. Солнечная, 3, г. Винница, 21008, (e-mail: ellens @ meta.ua).

\section{УДК 338.24}

DOI: 10.37128/2411-4413-2020-1-5

ІНСТИТУЦЙНІ
СТИМУЛИ
ПІДВИЩЕННЯ
ЕФЕКТИВНОСТІ
ДЕРЖАВНОГО
СЕКТОРУ ПРИ
ДЕЦЕНТРАЛЗЗАІІ

У статті досліджено особливості впливу інституційних стимулів та інструментів влади на ефективність децентралізації при забезпеченні добробуту та в контексті економічного зростання.

Мета статті - визначити інструменти влади та надати характеристику методам їхнього використання для стимулювання децентралізації, а також механізмам фінансування органів місиевого самоврядування, децентралізачії інформачії та визначити їхню роль у застосуванні ринкових стимулів для децентралізації.

Для дослідження особливостей інструментів влади та інституиійних стимулів децентралізації, визначення умов ефективної роботи механізмів фінансування місцевих урядів, переваг децентралізаиії інформаиї та типів ринкових стимулів було використано методологію кабінетних досліджень з аналізом опублікованих в іноземній літературі результатів теоретичних та прикладних досліджень. Використано вторинну інформацію об’єднану контекстом досвіду впровадження реформ з децентралізаиії державної влади, особливостей інституиійного середовища та встановлення стимулюючих чинників підвищення ефективності державної влади.

Інституичійні стимули для підвищення ефрективності децентралізаиії мають складну ієрархічну структуру, а їхній вплив залежить від багатьох чинників місцевої культури та традииій управління. Децентралізація інформації та різні ринкові стимули також можуть мати різну ефективність у їхньому застосуванні. У будь-якому випадку необхідними $\epsilon$ 尺ี численні зміни у політичній системі.

У подальших дослідженнях планується зосередити увагу на особливостях аั децентралізації в окремих регіонах України та надати оцінку стану реалізації запропонованих механізмів фінансування місиевих урядів у конкретних умовах. 